Peer-Reviewed Article

ISSN: 2162-3104 Print/ ISSN: 2166-3750 Online

Volume 6, Issue 2 (2016), pp. 367-393

(C) Journal of International Students

http://jistudents.org/

\title{
International Students' Perceptions of Race and Socio-Economic Status in an American Higher Education Landscape
}

\author{
Zachary S. Ritter \\ University of Redlands, California (USA)
}

\begin{abstract}
International students add a great deal of cultural and intellectual diversity to college campuses, but they also bring racial stereotypes and socio-economic status hierarchies that can affect campus climate. Forty-seven interviews with Chinese, Japanese, and South Korean international students were conducted. Results indicated that a majority of students had racial and status hierarchies and harbored prejudices toward African-Americans and Southeast Asians. Perceptions of Asian-Americans were mixed. Negative perceptions of Latinos were learned in the U.S., however positive perceptions of Latinos were held by South Korean students who had lived in the U.S. longer. This status hierarchy correlated closely with a racial hierarchy. A lack of opportunities to interact with diverse students led to stereotype proliferation. More policies and programs must be created that reduce misunderstandings between international and domestic students.
\end{abstract}

Keywords: Racial Stereotypes; Cross-racial Interaction; International Students; Chinese Japanese and South Korean Students; Media Construction; Neoliberal Globalization 
As Lou Jing took a bow after her performance on China's version of American Idol, called Go! Oriental Angel! Chinese netizens were already flooding the blogosphere with comments such as "she never should have been born" and she should "get out of China" (Chang, 2009). The Chinese born 20-year-old woman, whom the hosts called "chocolate girl", happened to have a Chinese mother and an AfricanAmerican father. China Daily columnist Raymond Zhou commented that darker skin is viewed as less beautiful than white skin, due to historical class distinctions in which field laborers were tanned while the privileged were pale (Doran, 2009). Similar instances of racial hierarchies exist in Japan (Russell, 1991) as well as South Korea (Kim, 2008), and may be influencing how East Asian international students are interacting with domestic students on American college campuses.

In the 2012-2013 academic year, the number of enrolled international students studying in the U.S. rose to 819,644 . University of California at Los Angeles (UCLA), ranked sixth in the nation, with 6,703 international students out of a total student body of 42,163 (Institute of International Education, 2012). A rising generation of affluent students from China, India, South Korea, and Saudi Arabia are flocking to American elite universities in order to build a brighter future for themselves, while American universities woo these students because they bring a great deal of money. In 2013-2014 alone, international students contributed $\$ 26.8$ billion to the U.S. economy (NAFSA, 2014). These trends are in line with a neoliberal view of higher education, wherein a global hierarchy of educational status is created. International students (customers), vie to get into the doors of the highest ranked universities (vendors of knowledge/diplomas) in an effort to gain a greater socio-economic standing (career), upon exiting college (Barrow, Didou-Aupetit \& Mallea, 2003; Zheng, 2010). International students from Asia often migrate to Europe, Australia, or the U.S., in order to gain prestige and global cultural capital (Apple, 2000; Kim, 2011). The governments of China, Japan (to a lesser extent), South Korea, and the U.S. support international student mobility because Asian countries receive highly educated workers that will stimulate their economies (Kim, 2011).

This desire to receive a western higher education, on the part of East Asian international students, results in a hierarchy of desired 
cultural capital, which prioritizes English speaking white culture over other non-white cultures, which leads to a hierarchy of races/ethnicities in the minds of some international students (Grant \& Lee, 2009). This study operates upon the foundation that Critical Race and White Supremacy theorists assert: global political, economic, and cultural systems are overwhelmingly controlled by whites, and are dominated, consciously or unconsciously (through media, education, and law) by a white-centric global ethos (Ansley, 1997; Bonnett, 1997; Delgado \& Stefancic, 2001; hooks, 1989). In this study, Global Position Conflict (Marginson, 2008), the notion that there is a global competition for ranking and status of higher education among international students (Brown, 2000; Kim, 2011; Marginson, 2008; Marginson \& Sawir, 2005), is combined with White Supremacist Thought; creating an environment where international students must operate in the shadow of an often U.S. hegemonic educational framework as well as a U.S. racial hierarchical script. The unconscious adoption of this racial script, combined with a pursuit for prestige/global cultural capital (Bourdieu, 1986; Kim, 2008), may prevent international students from interacting with certain racial outgroups based on stereotypical notions of white, African-American, Latino, and Asian-American students.

Although some scholars have focused on discrimination and racism geared toward international students (Hanassab, 2006; Lee, 2007; Spencer-Rodgers, 2001), the literature is sparse when it comes to international students' racial attitudes towards Americans. As international student numbers increase (Institute of International Education, 2013), racial tensions are bound to arise. Tensions came to a head at UCLA when an anti-Asian video was uploaded to YouTube. The white female student in the video complained and mocked the "hordes" of Asian students at UCLA and their lack of American-style manners (Parkinson-Morgan, 2011). This incident resulted in an uproar from the UCLA community, death threats to the student who posted it, and the eventual departure of the student from UCLA. Another example of tensions between domestic and international students occurred at Columbia University, where the line "We need to get rid of those Black people in Harlem," received much laughter from a Chinese audience in a Chinese Scholars and Students Association play (Cheng, 2011). The racist dialogue was in reference 
to an incident at Columbia University in which Ming-Hui Yu, a graduate statistics student, was struck dead by a car after fleeing a fourteen-year-old African-American assailant near the university (Amzallag, Peacocke, \& Pianin, 2008).

The campus climate literature has explored racial tensions between various groups in college (Brown, 2000; Reid \& Radhakrishnan, 2003), but almost no research has been conducted on how international students perceive and interact with racial diversity on U.S. campuses. Hurtado, Milem, Clayton-Pedersen, and Allen (1999) suggest that there are four dimensions that make up campus climate, including 1) institution's historical legacy, 2) structural diversity, or the statistical representation of diverse groups oncampus, 3) the psychological climate, namely perceptions and attitudes between groups, and 4) the behavioral climate, meaning the types of intergroup relations. When structural diversity is increased (as illustrated in the increasing numbers of international students), without thinking about how this will affect the other three dimensions of climate, problems are bound to arise (Milem, 2001).

As this population grows, researchers must take a closer look at racial attitudes of these students who will become future leaders in both the U.S. and their home countries. If the higher education community hopes to promote a democratic, multicultural society and racial tolerance (UC Diversity Mission Statement, 2012), then we must understand international students' racial stereotypes. Research has illustrated the positive effects of cross-racial interaction, such as development of cognitive abilities (Astin, 1993a), leadership skills (Antonio, 2001), and college satisfaction (Chang, 1999), but more research is needed on how international students form racial stereotypes and how these stereotypes may affect domesticinternational student relationships.

This study focuses on Chinese, South Korean, and Japanese international students' perceptions of race, looking specifically at:

1) What racial, ethnic, cultural stereotypes do East Asian international students bring to UCLA?

2) How are UCLA East Asian international students' racial, ethnic, and cultural stereotypes challenged, or reinforced, through college experiences? 


\section{LITERATURE REVIEW}

This literature review will look at the increase in international students on colleges across the U.S., how media influences international students' racial stereotypes, and how some of these racial stereotypes can affect cross-racial interactions on college campuses.

\section{Increase in International Student Enrollment}

The number of international students in U.S. colleges and universities has nearly doubled in the last two decades from 366, 354 in 1988-89 to 819,644 in 2012-13 (Institute of International Education, 2013). Chinese and South Korean students have comprised the largest influx of students. In the 2011-2012 academic year, the international student population included 194,029 Chinese, 100,270 Indian, 72,295 South Korean, and 19,966 Japanese students (Institute of International Education, 2012).

This new generation of international students has been referred to as the students of the new global elite (SONGEs) (Vandrick, 2011). These students often come from higher socioeconomic backgrounds; therefore, they can afford the high tuition costs of U.S. universities. These students often attended international schools, have lived, studied, and vacationed in various places around the world, and desire the prestige of a U.S. college degree (Brown, 2000; Kim, 2011; Marginson, 2008; Marginson \& Sawir, 2005) making them consumers of a global cultural capital (Bourdieu, 1986). There is an understanding among this population that understanding different cultures helps in a variety of career paths, but it does not appear that there is a firm understanding of racial power and oppression present in the majority of international students studying in the U.S. (Ansley, 1997; Delgado \& Stefancic, 2001). SONGEs' backgrounds, attitudes, and beliefs affect the college classrooms, interactions with instructors, the campus as a whole, and even the global workforce after graduation (Vandrick, 2011). Thus, it is imperative to understand the racial attitudes and stereotypes of this new elite, so that institutions, faculty, staff, and policy makers can create more student services for international students, while also 
finding avenues with which to aid in prejudice reduction and tolerance building amongst this community.

\section{Media Exposure}

Exposure to media plays a significant role in shaping individuals' racial attitudes, especially toward African-Americans and Latinos (Gilliam, Valentino, \& Beckmann, 2002). Portrayals of African-Americans as criminals on news broadcasts have been shown to promulgate negative stereotypes among white Americans (Larson, 2006). International students receive many of their stereotypes about American racial groups through media (Fujioka, 2000). Cultivation theory (Gerbner, 2009) posits that messages from TV are cumulatively internalized and if consumed over a long period of time, are believed to be true (Fujioka, 2000). International students may be coming to U.S. universities with a racial hierarchy that was learned through American media. Throughout American film and television history, African-Americans have been depicted as villainous, dim, and indigent, while European-Americans have been portrayed as heroic, intelligent, and powerful (Larson, 2006). These racialized images have created a racial hierarchy in international students' minds that affect how and with whom they interact (Perse, 2001; Russell, 1991). Unless positive, cross-racial, real-life contact is realized, racial prejudice will remain (Allport, 1954; Pettigrew, 1998).

\section{Cross-Racial Interaction}

Allport's (1954) contact hypothesis indicates that frequent contact with out-group members can foster positive inter-group attitudes, which can provide a model for how to enhance communication between international and domestic students. Allport specifies several different features that contact experiences must have in order to lessen prejudice: equal status between groups, common goals, inter-group cooperation, and the support of authorities, laws or customs. Pettigrew (1998) proposed another condition: time for cross group friendships to develop. Dinh, Weinstein, Nemon, and Rondeau (2008) surveyed white undergraduates at a large public university, asking about their cross-racial interaction with people of Asian descent. Findings revealed that white students, who reported more intercultural contact with Asian and Asian-American students, also 
reported more positive attitudes toward these groups. Cross-racial interaction in residential halls has also proven to be effective in changing racial attitudes (Shook \& Fazio, 2008). Even in residential halls, international students may feel hesitant to interact with domestic students due to language issues, personal bias, and cultural differences (Kimmel \& Volet, 2012). However, once international and domestic students interact, personal growth, improved language abilities, and a greater interest in cross-cultural interactions are common outcomes (Jon, 2013).

Cross-racial interaction also depends on geographic and social context. In a study looking at race relations in a Rocky Mountain university, white students were more comfortable interacting with African-American students than with Latino students because there were fewer African-American students, therefore, they were viewed as less of a threat in terms of academic and social competition (Smith, Bowman, \& Hsu, 2007). East Asian international student surveys at the same university indicated that they felt the least comfortable interacting with African-American students, but felt the most comfortable interacting with white students, which the researchers indicated may stem from Asian media portrayals of whites as attractive and successful (Smith, et. al, 2007). Due to stereotypes that some of the East Asian students held, white students represented a high socio-economic standing in society, therefore they were a more desirable out-group with which to interact.

For East Asian students, racial attitudes toward white students appeared to be more positive than attitudes towards African-American students. (Talbot, Geelhoed, \& Ninggal, 1999). East Asian international students view African-Americans as violent and rude, which were stereotypes gleaned from movies and home country news reports. Simultaneously, students who learned about the Civil Rights Movement in their home countries felt sympathy for the AfricanAmerican struggle for equality (Talbot et. al, 1999). In another study, when Japanese students, in Japan, were asked who they would most want to learn English from, a majority desired white teachers, rather than Latino or African-American English speakers because of the idealized construct of Western whiteness in Japanese society, and globally (Kobayashi, 2010). With an increasing population of international students bringing racial stereotypes with them to U.S. 
universities, how, if at all, do these stereotypes change as international and domestic students interact on campus?

\section{RESEACH METHOD}

\section{Study Participants}

The current study was conducted between 2010-2013 at UCLA, due to the ethnic and international diversity of the campus, in addition to being the location of the researcher's PhD studies. The researcher conducted semi-structured interviews with international students predominantly from China, Japan, and South Korea. Chinese and South Korean international students were chosen because they comprise two out of the three largest international student populations studying in the U.S. (Chinese, Indian, and Korean international students have the largest U.S. college enrollment numbers, respectively). Indian and Middle Eastern students were not included in this study because the researcher wanted to keep the cultural continuity of East Asian international students. The researcher interviewed graduate and undergraduate students to investigate whether there were different experiences between these two student groups.

The researcher conducted forty-seven 60-90 minute semistructured interviews, in English, with East Asian international students from China (23), South Korea (8), Japan (13), Hong Kong (2), and Taiwan (1). (Appendix B). The researcher recruited study participants from the UCLA International Center's language circles, International Center American culture workshops, residential life programs, the counseling center, and eventually through snowball sampling. Twenty-seven undergraduates and twenty graduate students were interviewed, with nineteen males and twenty-eight females. Each interview was conducted between the researcher and one interviewee (Appendix A). These students were from a variety of academic disciplines, and a mixture of time spent in the U.S., ranging from 1 month to 5 years.

\section{Validity}

All semi-structured interviews were audio recorded and transcribed verbatim by the researcher. In addition, notes were taken 
during the interviews, and member-checks were utilized (Lincoln \& Guba, 1986). Additionally, peer debriefing was used, in order to enhance the accuracy of the accounts.

\section{Data Analysis}

Interview transcripts were read multiple times and emergent themes were coded by hand. Microsoft Word documents were made to help keep track of themes that developed from interviewee quotations. These themes included, but were not limited to: home country racial/ethnic diversity, Gross Domestic Product and racial/economic hierarchies, perceptions of campus climate, and cross-racial stereotype change. The researcher employed a constant comparative method (Glaser, 1965), whereby some codes were predetermined by the literature, while others were data-driven codes. Codes included stereotypes before entry to the U.S., stereotype change that occurred while in college environment, and student affairs spaces and programs that helped encourage stereotype reduction. The researcher conducted three stages of coding: open coding, axial coding, and selective coding (Strauss \& Corbin, 1998).

\section{RESULTS AND DISCUSSION}

\section{Racial and Socio-Economic Status Hierarchies}

A notion of racial and socio-economic status hierarchies in which white people were at the zenith, East Asian people were second, Latino people were third, and African-Americans and Southeast Asian people at the bottom, were prevalent throughout the interviews and were consistent with the ideas presented in the White Supremacy Theory and Global Positional Conflict (Ansley, 1997; Delgado \& Stefancic, 2001; Marginson, 2008). Jay, a mid-thirties South Korean police officer, turned political science graduate student, who lived off-campus, described his perception of race in South Korea:

Many Koreans think white people are superior to Asian people and second is East Asian people and it's kind of my stereotype. In my opinion many people think African- 
American people and Southeast Asian people are inferior to East Asian or White Caucasian people.

$$
\text { (Jay, Male, 34, South Korea) }
$$

It was presumed that negative stereotypes were passed down from parents to their children, regarding African-Americans. As for stereotypes toward Southeast Asians, students explained that the darker skin color and perceived cultural and economic superiority of Korea led to several extreme cases of Korean farmers killing their Filipina and Vietnamese brides (Le, 2011). In an effort to explain, a Korean student said that historically, South Korea has been a very hierarchical, country, even racially, due to Confucianism and dynastic rule (Dikotter, 1992; Johnson, 2007). But this racial/status hierarchy was not only held by South Korean international students:

The structure of the world was made by white people, I think Asian people think that white culture is a little higher than Asian culture. We are proud of our culture, but you can't help the fact that white people created all the structures in the world. Also Japan was democratized by Americans, and maybe that's why I think American is a bit higher than Japanese.

(Keiko, Female, 23, Japan)

This racial hierarchy appears to be closely tied to hierarchies of socioeconomic status/global cultural capital (Bourdieu, 1986), which relates to educational prestige pursuits in the U.S. Jay, the first student quoted above, decided to come to the U.S. to earn a Ph.D. in public policy because he believed that in Korean society, being a professor was more prestigious than being a doctor or a lawyer. Twenty-four of the forty-seven students indicated that they held constructs of a racial global hierarchy, which they learned as children and affected how they viewed the world. This racial hierarchy was also part of a global status hierarchy that was closely tied to international students' goal of studying in the U.S.

Vandrick's (2011) findings corroborated the current study's findings: One of the major reasons international students came to the U.S. was to learn English, gain a better education, and improve one's 
status in one's home country. Reponses from the interviews indicated that improving one's status was intrinsically connected to a racial/financial status hierarchy. Learning English and studying in America were often associated with white people, thus leading to the perception that African-Americans, Latinos, and Asian-Americans were not optimal to befriend or interact with. Students chose to study in America because they felt their opportunities in the future would be greatly enhanced by learning English and earning an American degree. Many East Asian international students came from racially homogenous, yet ethnically diverse countries. However, they were often not exposed to the ethnic diversity in their home countries because they lived in metropolitan areas, were raised by affluent families, and identified with the majority ethnic groups in their countries. Internatonal students who attended high school in the U.S., attended international school, or were exposed to racial/ethnic diversity at a young age, were more likely to hold tolerant attitudes toward racial out-groups.

Amongst the students interviewed, it became apparent that a lack of historical knowledge regarding U.S. race relations, led to a reliance on media and day-to-day observations to piece together racial dynamics in the U.S. A majority of international students said they learned in their home country high school that the U.S. was not a melting pot. Rather, they learned the U.S. was a salad bowl where different racial/ethnic groups lived, often separate lives from one another. Eighty percent of international students learned about Martin Luther King Jr. in their high schools, but explained it was only one page out of the textbook and was somewhat abstract because they had little interaction with African-Americans. The struggle for Latino civil rights in America was unfamiliar to international students, as was the name Cesar Chavez. Ja-Sun, a South Korean humanities undergraduate who lived in the U.S. for 5 years explained that many people in South Korea do not come into contact with foreigners, therefore they "freak out" when they see people that look different from themselves. Over half of international students interviewed explained that they did not have many stereotypes of Latino people, but quickly and wrongly inferred that Latino people were mostly working-class and had large families, due to observations that international students made by riding public transportation. In the 
absence of contact and in-depth historical understanding of a racial/ethnic out-group, negative stereotypes emerge (Peng, 2010).

\section{Perceptions of African-American People}

International students were asked about their views toward African-Americans prior to arriving in the U.S. and seventy percent said they held negative views toward this group. Findings indicated that media, family/friends, and historical precedents, all fed into negative stereotypes of African-Americans. Linzy, a South Korean undergraduate who went to high school in Canada, explained that prior to attending UCLA, she viewed African-Americans as a threat:

Well I was scared [of them]. I know it sounds terrible. I don't want to lie. But I think it is the media's fault because I watch the movies and I see big guys, drug dealing and I saw the big aggressive guys are tough and they shoot. I thought only black people are very violent and aggressive. If you never met them, you would be scared. I think I still have a little, you know. If you never met them I think I'd be scared.

(Linzy, Female, 23, South Korea)

A majority of students credited films like Crash, NBA basketball games, and hip hop videos for inculcating them with ideas that African-Americans were dangerous, aggressive, good at dancing, and athletic (Fujioka, 2000; Johnson, 2007; Russell, 1991; Talbot et al., 1999; Tan, Zhang, Dalisay, \& Zhang 2009). International students were heavily influenced by American media that portrayed AfricanAmericans mostly in a negative light and white people in a positive light. Hank, a Chinese engineering student, explained that it was not only American media that was perpetuating stereotypes of AfricanAmericans as aggressive and violent people:

In this Chinese TV drama, it is about this guy who goes to America and gets robbed by a black guy and that is the only time a black guy appears in the movie. So if I'm a Chinese person, what do you think I'm going to think of black people? 'Oh man, better watch out for black people when I come to America!' That's how it was dude! (Hank, Male, 22, China) 
Hank felt it was only natural that Chinese people would internalize images of violent African-Americans because it is promulgated widely in media. Cultivation Theory (Gerbner, 2009) posits that the more these images are consumed, the more they are internalized as 'truth' from the media consumer's perspective.

Cultivated stereotypical images combined with a lack of physical contact with a given out-group results in perpetuation of prejudice (Fujioka, 2000). According to Hurtado et al. (2003), a vital part of creating a campus climate that promotes racial tolerance, starts with a tolerant psychological climate. This refers to the attitudes one group has toward another group. If international students are entering UCLA with negative attitudes toward certain groups, or concocting negative stereotypes through a lack of interaction and consumption of media, then the goal of creating a racially tolerant campus is in jeopardy.

\section{Perceptions of Latino People}

When asked if international students had stereotypes or ideas about Latino people prior to coming to America, sixty percent said they did not have any ideas about this group because they did not see this racial group in their home country, nor in popular media (Rivadeneyra, 2006). More than thirty percent of students grouped African-Americans and Latinos together as being of lower economic status and more prone to commit robberies. Older international students who had been in the U.S. for two years or more perpetuated negative stereotypes. These older international students warned newly arrived co-nationals that Latino people were likely to rob them in certain neighborhoods. However, South Korean students, who had stayed in the country longer, expressed a sense of camaraderie with Latinos due to common immigrant values of hard work and family unity.

Students had some vague ideas that Latino people had pretty eyes and were good at soccer, but when it came to identifying Latino people, a majority of students could not tell the difference between white and Latino people. Many students developed ideas about Latino people through daily experiences and observing their surroundings in the Los Angeles area: 
I didn't know much about them before I came here. I think my stereotype is after I came here, because I saw, in our dining hall, that the workers are mainly Mexican-American workers. So I think they don't receive as much education as the white man. Because the worker who is repairing the bathroom and pool of my aunt's house are all Mexicans, and the people who work in [university cafeteria], they are Mexican Americans too, doing the lower jobs. So I formed a stereotype about them. And at orientation, there is a boy who said that he is the first from his community to ever come to the college.

(Mingqu, Female, 18, China)

Mingqu saw that Mexican-American people were doing menial jobs at UCLA and at her aunt's house; therefore, she developed ideas that many Latinos were working class people. She even met a Latino student who explained that he was a first generation college student, further feeding into her stereotype that Latinos had financial difficulty sending their children to college. Other students did not know what Latino meant, and were erroneously educated by domestic students. Dae, a South Korean humanities undergraduate student, studying at UCLA for three months was confused by what Latino meant and asked her friends to explain. She saw a blond haired, Brazilian man, and thought he looked American. Her friend said: "[Brazilians] are not Latino, only Mexicans are Latinos" and went on to explain how she thought Brazilians were more beautiful and wealthier than Mexicans. This statement gave Dae the impression that the term Latino connoted someone who was lower-class and had darker skin. Even when international students sought clarification from domestic students as to how to interpret the racial diversity around them, they sometimes adopted the prejudices of their domestic counterparts.

While Chinese and Japanese students were not very familiar with Latino culture, four out of eight South Korean students not only knew something about Latino culture, but felt that there were commonalities that Latino and South Korean people shared:

To tell you the truth I love Latino students. We get along really well! Basically the family values we share, because Latino/Latina culture really value families right? Probably 
because they are Catholic, I don't know. I grew up Catholic so that is one reason I felt comfortable being with Latino and Latina people. And even from my MA program, my two best friends are Latinas.

(Yoon, Female, 28, Korea)

Yoon was a graduate student in the humanities who had taken courses on diversity and was in classes where she was able to interact with Latino students. Diversity courses have been shown to increase cultural awareness (Chang, 2002) and it was clear those students who had taken diversity courses and lived in residential halls where crosscultural interaction was encouraged, were more active in dismantling racial hierarchies and challenging stereotypes. South Korean graduate students who had taken diversity courses thought Latinos shared strong family values, children's respect for parents, belief in the American rags-to-riches dream, and Christian values (Min, 2007). Several South Korean students who did interact with Latino students did find that there were more similarities than differences, indicating that positive contact could reveal commonalities between groups.

\section{The Complexities of Asian and Asian-American Relations}

Many of the study participants chose to attend UCLA because they thought they would have less culture shock at a university with a large Asian-American population. International students anticipated a cultural and social closeness with Asian-American students, but for the most part, Asian-American students were thought to be too Americanized and were unwilling to interact with Asian internationals.

East Asian international students had few preconceived notions of Asian-American students prior to arrival, because there was a dearth of media portrayals of this group in film, television, and news. There was, however, an understanding that UCLA had a large population of Asian-American and Asian international students. International students were pleased at how many Asian looking students were at UCLA when they arrived, however, they quickly realized there was a cultural barrier between the two groups, which led to a lack of interaction. 
More than half of students interviewed said that AsianAmericans were Americanized, however, one-third, mostly from the science fields, felt that Asian-Americans were caught between being Asian and being American. Han, a Chinese science graduate student, who lived in America for three years, explained his perceptions of Asian-Americans:

I feel a little sad about [Asian-Americans] because they are not really American, they are not really Asian. Most of the times they are with another American-born Chinese. They form like a small group, which is kind of pathetic, it's not good for them, they are kind of isolated.

(Han, Male, 26, China)

Han, a material science graduate student, felt that Asian-Americans were left out of both Asian international and white social circles. Han may have been referring to the fact that some students in the STEM (Science, Technology, Engineering, Mathematics) fields came from immigrant families, faced linguistic and cultural barriers on campus, and as a result, felt more comfortable interacting with Asian international students. On the other hand, international students in humanities majors viewed Asian-American as identical to white Americans. Asian international students were disappointed by the lack of interaction on the part of Asian-Americans in the humanities.

There was variation amongst the international students interviewed, which can be explained by three types or groups of participants. The first were students of the new global elite (Vandrick, 2011). These students were more aware of racial diversity in East Asia and in the U.S., but still held notions of a global racial and educational hierarchy presented in the media and societal observations. Graduate humanities students often fell into part of the new global elite, however, those who had lived in America for 3-5 years, were exposed to diversity in their everyday lives and coursework, and were much more likely to speak out against racial and educational hierarchies. Second, undergraduate students who had taken a diversity course and lived with racially diverse roommates for 5-12 months were beginning to question the racial hierarchy script delivered in media. Third, graduate and undergraduate students, who 
lived off-campus with co-nationals, had few racially diverse friends, were science majors (these classes were less racially diverse), and had little exposure to diversity courses/international center programming, were more likely to accept the European-centric racial hierarchy portrayed in the media (Delgado \& Stefancic, 2001; hooks, 1989).

\section{Limitations}

A limitation in this study was the lack of deeper analysis regarding the heterogeneity that exists within the Chinese, Japanese, and South Korean populations being studied. The literature review paints a historical picture of bias and racism, but this does not mean that the ideas expressed in the interviews were held by all East Asian international students. The study illustrated that some students from China, Japan, and Korea did have racist attitudes; however, this was only a qualitative study of 47 students. The study by no means seeks to indicate that all students from these countries hold negative attitudes toward American racial minority groups. In order to be more generalizable, there must be a quantitative study, with a larger population size, that includes more Asian countries.

\section{IMPLICATIONS AND CONCLUSION}

This research begs the question of whether these results would have been different if white American students were asked similar questions regarding their stereotypes. American college students may hold similar global racial hierarchies, but have been taught to speak in a politically correct manner, when talking about people with darker skin or non-white features (Norton, Sommers, Apfelbaum, Pura, \& Ariely, 2006). One way to ameliorate this issue is not to teach international students how to adopt a politically correct lexicon, but to teach classes that discuss racial politics and civil rights movements in America, deconstruct Hollywood portrayals of racial groups, and teach inter-cultural communication skills (Chang, 2002).

UCLA International Center programs were effective in exposing international students to racial diversity; however, there must be a more concerted effort to expose and educate East Asian 
International students about African-American and Latino heritage and history (Hurtado, Dey, Gurin, \& Gurin, 2003). The Intergroup Dialogue Program (a for-credit identity-based dialogue college course) created at the University of Michigan, encourages students to challenge their racial perceptions through experiential learning, talking about privilege and oppression and conducting community action projects that bring together disparate racial communities (Zúñiga, Nagda, \& Sevig, 2002). UCLA International Center programs such as Global Siblings, which pairs international students with domestic student mentors should be expanded. It would also be beneficial to have an American history/government requirement for international students, that also discuss race relations in a U.S. context. A stronger multicultural curriculum in the K-12 system in Asian countries would also be beneficial. Living-learning themed housing where international and domestic students have intentional programming around issues on diversity would be another way to infuse multicultural awareness into the international student experience.

Chinese and South Korean International students comprise two of the largest international student population groups studying in the U.S. (Institute of International Education, 2013). American scholars and student affairs officers must look more closely at diversity issues surrounding international student populations. East Asian International students are socialized in countries that are, for the most part, racially homogeneous, therefore they bring stereotypes and racial hierarchies that often times go unchallenged. These prejudices are not founded upon racial hatred, rather they are based on a lack of exposure, which could be ameliorated by educational instruction, student programming, and living-learning environments. If student affairs officers and faculty devote resources, time, and energy into educating this student population about American racial diversity, these members of the future global elite will go on to become productive and tolerant citizens in the global community.

\section{REFERENCES}

Allport, G. W. (1954). The nature of prejudice. Cambridge, MA: Addison-Wesley Publishing Company Inc. Astin, A. W. (1993a). Diversity and multiculturalism on the campus: 
How are students affected? Change, 23, 44-49.

Amzallag, D., Peacocke, A., \& Pianin, A. (2008). Grad student fled assault before killed by car; Suspect arrested for manslaughter. Columbia Spectator. Retrieved from http://www.columbiaspectator.com/2008/04/05/

Ansley, F.L. (1997). White supremacy (and what we should do about it). In R. Delgado \& J. Stefancic, J. (Eds.), Critical white studies: Looking behind the mirror (pp. 592-595). Philadelphia, PA: Temple University Press.

Antonio, A. L. (2001). The role of interracial interaction in the development of leadership skills and cultural knowledge and understanding. Research in Higher Education, 42(5) 593-617. Apple, M.W, (2000). Between neoliberalism and neoconservatism. In N.C. Burbules \& C.A Torres (Eds.), Globalization and education: Critical Perspectives (pp. 57-77). London, UK: Routledge.

Barrow, D.W., Didou-Aupetit, S., \& Mallea, J, (2003). Globalization, trade liberalization, and higher education in North America: The emergence of a new market under NAFTA? Dordrecht, the Netherlands: Kluwer Academic Publishers.

Bonnett, A. (1997) Constructions of whiteness in European and American anti-racism. In P. Werbner \& T. Modood (Eds.), Debating cultural hybridity: Multi-cultural identities and the politics of anti-racism (pp. 173-192). London, UK: Zed Books. Bourdieu, P. (1986) The forms of capital. In J. G. Richardson (Ed.), Handbook of theory and research for the sociology of education, (pp. 241-258). Westport, CT: Greenwood Press. Brown, P. (2000). The globalization of positional competition? Sociology 34(4) 633-53.

Chang, E. (2009). TV talent show exposes China's race issue. CNN World. Retrieved from http://www.cnn.com/2009/WORLD/asiapcf/12/21/china.race/ Chang, M. J. (2002). The Impact of an undergraduate diversity course requirement on students' racial views and attitudes. Journal of General Education, 51(1), 21-42.

Chang, M. J. (1999). Does racial diversity matter? The educational impact of a racially diverse undergraduate population. Journal of College Student Development, 40(4), 377- 395. 
Cheng, Y. (2011, September 01). From campus racism to cyber racism: Discourse of race and Chinese nationalism. China Quarterly, 207, 561-579.

Delgado, R., \& Stefancic, J. (2001). Critical race theory: An introduction. NY: New York University Press.

Dikotter, F. (1992). The discourse of race in modern China. Stanford, CA: Stanford University Press.

Dinh, K., Weinstein, T., Nemon, M., \& Rondeau, S. (2008). The effects of contact with Asians and Asian Americans on White American college students: Attitudes, awareness of racial discrimination, and psychological adjustment. American Journal of Community Psychology, 42(3-4), 298-308.

Doran, D. (2009). Reality TV show exposes racism in China. The Telegraph. Retrieved from http://www.telegraph.co.uk/expat/expatnews/6560168/RealityTV-show-exposes-racism-in-China.html

Fujioka, Y. (2000). Television portrayals and African-American stereotypes: Examination of television effects when direct content is lacking. Communication Abstracts, 23(1), 3-149.

Gerbner, G. (2009). Cultivation Theory. In M. Ryan, A First Look at Communication Theory. 7th ed. (pp. 353-354). New York, NY: Frank Mortimer.

Gilliam, F. D., Valentino, N. A., \& Beckmann, M. N. (2002). Where you live and what you watch: The impact of racial proximity and local television news on attitudes about race and crime. Political Research Quarterly, 55(4), 755-780.

Glaser, B. G. (1965). The constant comparative method of qualitative analysis. Social Problems, 12(4), 436-445.

Grant, R. A., \& Lee, I. (2009). The ideal English speaker. In R.

Kubota, \& A. M. Y. Lin, Race, culture, and identities in second language education: Exploring critically engaged practice. NY: Routledge.

Hanassab, S. (2006). Diversity, international students, and perceived discrimination: Implications for educators and counselors. Journal of Studies in International Education, 10(2), 157-172.

hooks, b. (1989) Talking back: Thinking feminist. Thinking black.

Boston, MA: South End Press.

Hurtado, S., Dey, E. L., Gurin, P., \& Gurin, G. (2003). College 
environments, diversity, and student learning. In J.C. Smart (Ed.), Higher education: Handbook of theory and research 18, (pp. 145-90). UK: Kluwer Academic Publishers.

Hurtado, S., Milem, J., Clayton-Pedersen, A., \& Allen, W. (1999).

Enacting diverse learning environments: Improving the campus climate for racial/ethnic diversity (ASHE/ERIC Higher Education Reports Series, 26, no. 8). Washington, DC: George Washington University/ERIC Clearinghouse on Higher Education.

Institute of International Education. (2012). Press release: Record numbers of international students in U.S. higher education. Retrieved from http://www.iie.org Institute of International Education. (2013). Open Doors Data on International Students. Retrieved from http://www.iie.org/Research-and-Publications/OpenDoors/Data/International-Students.aspx Jon, J.-E. (2013). Realizing internationalization at home in Korean higher education promoting domestic students' interaction with international students and intercultural competence. Journal of Studies in International Education, 17(4), 455-470. Johnson, D. (2007). Race and racism in the Chinas: Chinese racial attitudes toward Africans and African-Americans.

Bloomington, IN: Author House.

Kim, N. (2008). Imperial citizens: Koreans and Race from Seoul to LA. Stanford, CA: Stanford University Press.

Kim, J. (2011). Aspiration for global cultural capital in the stratified realm of global higher education: why do Korean students go to US graduate schools? British Journal of Sociology of Education, 32(1), 109-126.

Kimmel, K., \& Volet, S. (2012). University students' perceptions of and attitudes towards culturally diverse group work: Does context matter? Journal of Studies in International Education, 16, 157-181.

Kobayashi, Y. (2010). Discriminatory attitudes toward intercultural communication in domestic and overseas contexts. Higher Education, 59(3), 323-333.

Larson, S. G. (2006). Media \& minorities: The politics of race in news and entertainment. Lanham,MD: Rowman \& Littlefield. 
Le, J. (2011, June 8). Till death do us part: Foreign Vietnamese bride killed in South Korea. Vietnam Talking Points: One Vietnam Network. Retrieved from http://talk.onevietnam.org/til-deathdo-us-part-foreign-vietnamese-bride-killed-in-south-korea/

Lee, J. (2007). Bottomline: Neo-racism toward international students. about campus, 11(6), 28-30.

Lincoln, Y.S., \& Guba, E.G. (1986). But is it rigorous?

Trustworthiness and authenticity in naturalistic evaluation.

New Directions for Program Evaluation, 30, 73-84.

Marginson, S. (2008). Global field and global imaging: Bourdieu and

worldwide higher education. British Journal of Sociology of Education, 29(3), 303-15.

Marginson, S., \& E. Sawir. (2005). Interrogating global flows in higher education. Globalization, Societies, and Education, $3(3), 281-310$.

Milem, J. (2001). Increasing diversity benefits: How campus climate and teaching methods affect student outcomes. In G. Orfield, M. Kurlaender, \& Civil Rights Project (Harvard University), Diversity challenged: Evidence on the impact of affirmative action. Cambridge, MA: Harvard Education Pub. Group.

Min, P.G. (2007). Korean-Latino relations in Los Angeles and New

York. Du Bois Review: Social Science Research on Race, 4(2).

NASFA (2014). The international student economic value tool.

Retrieved from http://www.nafsa.org/Explore_International_Education/Impact/ Data_And_Statistics/The_International_Student_Economic_Val ue_Tool/

Norton, M., Sommers, S. Apfelbaum, E., Pura, N., \& Ariely, D. (2006). Color Blindness and interracial interaction: Playing the political correctness game. Psychological Science, 17(11), 949. Parkinson-Morgan, K. (2011, March 14). Updated: UCLA student's YouTube video 'Asians in the Library' prompts death threats; violent responses criticized as equally damaging. Retrieved from http://dailybruin.com/2011/03/14/ucla_student039s_youtube_vi deo_039asians_in_he_library039_prompts_death_threats_viole nt_responses_c/

Peng, S.-Y. (2010). Impact of stereotypes on intercultural 
communication: a Chinese perspective. Asia Pacific Education Review, 11(2), 243-252.

Perse, E. M. (2001). Media effects and society. Mahwah, NJ:

Lawrence Erlbaum.

Pettigrew, T. (1998). Intergroup contact theory. Annual Review of Psychology, 49, 65-85.

Reid, L. D., \& Radhakrishnan, P. (2003). Race matters: The relation between race and general campus climate. Cultural Diversity \& Ethnic Minority Psychology, 9(3) 263-75.

Russell, J. (January 01, 1991). Race and Reflexivity: The black other in contemporary Japanese mass culture. Cultural Anthropology, 6(1), 3-25.

Shook, N. J., \& Fazio, R. H. (2008). Interracial roommate relationships: An experimental field test of the contact hypothesis. Psychological Science, 19(7), 717-23.

Smith, T. B., Bowman, R., \& Hsu, S. (2007). Racial attitudes among Asian and European American college students: A crosscultural examination. College Student Journal, 41(2), 436443.

Spencer-Rodgers, J. (2001). Consensual and individual stereotypic beliefs about international students among American host nationals. International Journal of Intercultural Relations, 25(6), 639-657.

Strauss, A., \& Corbin, J. (1998). Basics of qualitative research:

Techniques and procedures for developing grounded theory (2nd ed.). CA: Sage.

Tan, A., Zhang, Y., Dalisay, F., \& Zhang, L. (2009). Stereotypes of African Americans and media use among Chinese high school students. Howard Journal of Communications, 20(3) 260-275.

Talbot, D., Geelhoed, R., \& Ninggal, M. T. (1999). A qualitative study of Asian international students' attitudes toward African-Americans. NASPA Journal, 36(3), 210- 221

UC Diversity Mission Statement. (2012). Retrieved from http://www.gdnet.ucla.edu/gasaa/admissions/diversity.htm

UCLA, Undergraduate Admissions. (2013). Quick facts about UCLA. Retrieved from

http://www.admissions.ucla.edu/campusprofile.htm.

Vandrick, S. (2011). Students of the new global elite. TESOL 
Quarterly: Journal for Teachers of English to Speakers of Other Languages and of Standard English as a Second Dialect, 45(1), 160-169.

Zheng, J. (2010, August 01). Neoliberal globalization, higher education policies and international student flows: An exploratory case study of Chinese graduate student flows to Canada. Journal of Alternative Perspectives in the Social Sciences, 2(1), 216-244.

Zúñiga, X., Nagda, B. A., \& Sevig, T. D. (2002). Intergroup

dialogues: An educational model for cultivating engagement across differences. Equity and Excellence in Education, $35(1), 7-17$.

\section{Appendix A}

Interview Protocol

Introduction

1) Thank you for participating in this study. My name is [researcher's name], I am a [researcher describes him/herself]. The participant is then asked to introduce him/herself in the same manner.

Home Country Experience with Diversity

1) What do you think the majority of people in (student's country of origin) think about racial diversity in America?

2) What kind of racial/ethnic diversity exists in (students' country of origin)?

Thoughts about American Before Coming

3) Did you learn about different American ethnic groups in high school in your home country?

Probe $\rightarrow$ Did your friends (and family) tell you positive or negative things about a certain racial group?

4) Did you have any ideas about white-American people before you came to UCLA? If so, what were they? (Repeat this question for Latino, African-American, Asian-American people).

Probe $\rightarrow$ Where do you think you got these ideas from?

Probe $\rightarrow$ Did television or films play a role in the creation of these ideas? 
Campus Experience with Racial Diversity

5) Have you interacted with any of these racial groups at UCLA?

Probe $\rightarrow$ What was the nature of the interaction?

Probe $\rightarrow$ Where did this interaction take place?

6) How, if at all, did this interaction change your stereotype of this group?

Note: Look for stereotype change, 1) Conversion Model 2)

Bookkeeping Model 3) Subtyping Model 4) New Model

7) Who do you room with?

Probe $\rightarrow$ Do you get along with your roommate(s)?

Probe $\rightarrow$ Do you interact with people of different races in your living space?

8) Do you TA any courses or hold any leadership positions? races?

Probe $\rightarrow$ Do you interact differently with people of different

Dating (Code list: DA)

9) Have you or would you ever date someone outside your race/ethnicity?

Probe $\rightarrow$ Do societal racial ideas (stereotypes) affect your decision of a romantic partner?

10) Have your views toward (a given race group) changed during your stay at UCLA?

Probe $\rightarrow$ What do you think led to this change, or lack thereof?

Campus Programs and Suggestions

11) Have you attended any clubs or international student activities on campus? Probe $\rightarrow$ Who do you interact with at these clubs/organizations? Do you interact more with international students or domestic students at these events?

12) In international student orientation, was there talk about racial diversity and how to interact with different cultures on campus?

Probe $\rightarrow$ What are your feelings regarding UCLA's efforts to encourage racial diversity at UCLA? Do you think it is overemphasized or not emphasized enough at UCLA? 
Probe $\rightarrow$ How do you think UCLA could help international students interact and learn about racial diversity?

\section{Appendix B}

Student Information Chart

\begin{tabular}{|c|c|c|c|c|c|c|c|}
\hline Name & Age & Sex & $\begin{array}{l}\text { Home } \\
\text { Country }\end{array}$ & $\begin{array}{l}\text { College } \\
\text { Level }\end{array}$ & $\begin{array}{l}\text { Time in } \\
\text { America }\end{array}$ & Major & Living Space \\
\hline Rex & 20 & $\mathrm{M}$ & China & UG & 3-4 years & Engineering & On Campus \\
\hline Zhun & 23 & $\mathrm{~F}$ & China & UG & $1-3$ months & Engineering & Off Campus \\
\hline Rui & 19 & $\mathrm{~F}$ & China & UG & 1-2 months & Undeclared & On Campus \\
\hline Guo & 24 & M & China & UG & 3-4 years & Architecture & Off Campus \\
\hline Sherly & 21 & $\mathrm{~F}$ & China & UG & 1-3 months & English & Off Campus \\
\hline Bao & 23 & M & China & UG & 3-4 years & Math/Econ & Off Campus \\
\hline Han & 25 & M & China & UG & $1-3$ months & Science/Engineer & Off Campus \\
\hline Dae & 21 & $\mathrm{~F}$ & Korea & UG & $1-3$ months & Political science & Off Campus \\
\hline Linzy & 23 & $\mathrm{~F}$ & Korea & UG & 3-4 years & Psychology & Off Campus \\
\hline Jay & 34 & M & Korea & GR & 1-2 years & Public policy & Off Campus \\
\hline Himal & 45 & $\mathrm{~F}$ & Korea & GR & 1-2 years & Elec. Engineer & Off Campus \\
\hline Keiko & 23 & $\mathrm{~F}$ & Japan & UG & 4-6 months & Political Science & On Campus \\
\hline Hideki & 23 & M & Japan & UG & $1-3$ months & Comm. Studies & On Campus \\
\hline Shiso & 35 & $\mathrm{~F}$ & Japan & GR & 4-6 months & Computer Science & Off Campus \\
\hline Han & 26 & M & China & GR & 3-4 years & Science/Engineer & Off Campus \\
\hline Mei & 40 & $\mathrm{~F}$ & China & GR & 7-11 months & Education & Off Campus \\
\hline Gong & 27 & M & China & GR & $1-3$ months & Engineer & Off campus \\
\hline Sean & 23 & M & China & GR & 1-2 years & Engineer & Off campus \\
\hline Winnie & 25 & $\mathrm{~F}$ & China & GR & 4-6 months & Finance & Off campus \\
\hline Chin & 25 & M & China & GR & 4-6 months & Business & Off campus \\
\hline Amy & 24 & $\mathrm{~F}$ & China & GR & 4-6 months & Education & On Campus \\
\hline Hank & 22 & M & China & UG & $5+$ years & Economics & Off campus \\
\hline Zeek & 20 & M & China & UG & $1-3$ months & Sociology & On Campus \\
\hline Collin & 20 & M & China & UG & $1-3$ months & Physiological & On Campus \\
\hline Yenzi & 30 & $\mathrm{~F}$ & China & GR & 4-6 months & Biostatistics & Off campus \\
\hline Ally & 19 & $\mathrm{~F}$ & China & UG & 4-6 months & Psychobiology & On Campus \\
\hline Lan & 29 & $\mathrm{~F}$ & China & GR & 3-4 years & Engineer & Off campus \\
\hline Behao & 19 & M & China & UG & $1-3$ months & Economics & On Campus \\
\hline Mingqu & 18 & $\mathrm{~F}$ & China & UG & 4-6 months & Economics & On Campus \\
\hline Elena & 21 & $\mathrm{~F}$ & China & UG & $5+$ years & English & Off Campus \\
\hline Erin & 29 & $\mathrm{~F}$ & China & GR & 1-2 years & Cinema & Off campus \\
\hline Min & 32 & M & Taiwan & GR & $5+$ years & Management & Off campus \\
\hline Cattie & 23 & $\mathrm{~F}$ & China & GR & 4-6 months & Engineer & Off campus \\
\hline June & 21 & $\mathrm{~F}$ & Korea & UG & 3-4 years & Math/econ & On campus \\
\hline
\end{tabular}




\begin{tabular}{llllllll} 
Ja-Sun & 20 & F & Korea & UG & 5+ years & Psychology & On Campus \\
Young & 31 & F & Korea & GR & 1-2 years & Education & Off campus \\
Yoon & 28 & F & Korea & GR & 5+ years & Education & Off campus \\
Riu & 24 & M & Japan & UG & 1-3 months & Economics & Off campus \\
Momoko & 26 & F & Japan & UG & 5+ years & Asian studies & Off campus \\
Taka- & 24 & M & Japan & UG & 3-4 years & Political Science & On Campus \\
Yuki & 22 & F & Japan & UG & $1-3$ months & Economics & Off campus \\
Saiko & 30 & F & Japan & GR & $1-3$ months & Education & Off campus \\
Emiko & 22 & F & Japan & UG & $1-3$ months & Law & Off campus \\
Kosu & 22 & M & Japan & UG & 3-4 years & Political Science & Off campus \\
Kenny & 22 & M & Japan & UG & $1-3$ months & Engineer & On Campus \\
Cat & 26 & F & Japan & GR & $1-3$ months & Education & On Campus \\
Roko & 25 & F & Japan & GR & 5+ years & Anthropology & On Campus \\
\hline
\end{tabular}

Note $: \mathrm{UG}=$ Undergraduate, $\mathrm{GR}=$ Graduate

ZACHARY S. RITTER, PhD, is an Associate Director of Campus Diversity and Inclusion and an Adjunct Professor in the School of Education, University of Redlands, CA.

Email: zack_ritter@redlands.edu 